\title{
An Evaluation of the Relationship Between Integrated Rural Development Scheme, Livelihood Assets and Housing Condition in Nigeria
}

\author{
Odebode, Adedayo Ayodeji ${ }^{1} \quad$ Olatoye, Ojo $^{1} \quad$ Adisa Banji Olalere $^{2} \quad$ Olaniyan A.A. ${ }^{3}$ \\ 1.Department of Estate Management, \\ 2.Department of Agricultural Extension and Rural Sociology, Obafemi Awolowo University, Ile-Ife, Osun State \\ 3. Department of Estate Management, Osun State Polytechnic Iree, Nigeria
}

\begin{abstract}
The paper examined the relationship among integrated rural development scheme, livelihood assets and housing condition in selected rural areas in Osun state. This is necessitated by the need to look at an alternative ways of financing rural housing through self-help project. It is also inspired by the need for sustainability in better housing condition in the rural communities. The paper carried out a survey of participants of an existing integrated scheme that was established with the objective of improving farmers' welfare through improved productivity in 28 rural communities under the jurisdiction of Justice Development and Peace Makers' Centre (JDPMC), Osogbo, Osun state. Data was obtained from 344 respondents selected through a multi-staged sampling across 28 rural communities in Osun state. The data obtained was analysed with the use of frequency distribution, correlation, regression and chi-square analysis. The results of the study in this paper reveals, among others, that the mode of operation and housing condition has positive relationship and are not independent of each other. Similarly, there is significant relationship between household size $(\mathrm{r}=0.327)$ and housing condition, livelihood assets $(\mathrm{r}=0.451)$ and housing condition at $\mathrm{P} \leq 0.01$. Based on these findings, integrated scheme has positive relationship with housing condition because the more the livelihood assets through integrated scheme, the better the rural housing condition in Nigeria.The paper therefore suggests consideration of integrated scheme as an effective strategy for rural housing improvement. The study is a pioneering attempt at establishing whether increase in participants' assets such as physical, financial, natural, human and social capital due to the integrated scheme will lead to significant improvement in housing condition.
\end{abstract}

Keywords: relationship, integrated, rural development scheme, livelihood assets, housing condition, and rural areas.

DOI: $10.7176 / \mathrm{CER} / 12-5-06$

Publication date:May $31^{\text {st }} 2020$

\section{Introduction}

Rural areas in most cases are neglected in most parts of the world especially in a developing country like Nigeria. Nigeria's internal disparity between rural areas and urban areas is very high (Olayiwola and Adeleye, 2005). Rural areas remain poor and neglected despite its contribution to the national economy and Gross Domestic Product (GDP) (IFAD, 2011). This has accounted in most cases for the high rural urban migration as opined by Sule et al. (2013). Thus, the challenge of housing crises such as proliferation of shanty living areas experienced in Nigeria according to Sule et al. (2013) is a reflection of neglect of rural housing in particular and rural development in general. Provision of improved livelihood and housing in rural areas could be a good strategy for controlling rural urban migration which would have positive effect on urban housing as well by reducing pressure on urban housing needs. The Nigerian government in response to the housing problem in the country had evolved several housing policies such as Land Use Act, 1978, National Housing Policy, 1991 and third and fourth National Development Plans with the objectives of proffering solutions to housing problem.

However, most of these policies focused on urban housing, neglecting the rural areas. This is evidenced from appraisals of past government approaches towards housing delivery that revealed that they have not recorded notable success (Odebode and Oladokun, 2010).

Though housing problem is universal but, there are various dimensions to both urban and rural housing problems in different countries such as India, Bangladesh and Kenya among others. A review of housing policies of these countries revealed lack of commitment to rural housing (Kenya, 2004; Nahiduzzaman, 2012; and India, 2015).

Due to the lack of commitment from both the public and private organisations to embark on rural housing in these countries, they have embraced integrated housing development schemes as evidenced through the works of Majale (2004) and Lall and Lall (2006). Integrated housing development scheme is an effort, interpreted in terms of a holistic approach to poverty reduction through shelter and income improvement (Lall, 2002). This is achieved by integrating housing and income generating activities in the livelihood programmes of the partner groups in a project. Integrated housing development scheme therefore, is a process of inducting sustainability in the well- 
being/status of the poor at the post-project period through assessment of the relationship between income generation activities and housing improvement (Majale, 2004).

In any integrated scheme such as an integrated housing development scheme, the development strategy is the Sustainable Livelihood Approach (SLA). Sustainable Livelihood Approach (SLA) links issues of poverty reduction, sustainability and empowerment processes in a systemic and adaptive way (Morse et al. 2009). Hence, sustainability in this paper is being viewed from the ability to maintain the improved level of well-being (that is better housing condition) among the participants in the study area.

One of the feedbacks from the achievement of livelihood outcomes in the Department for International Development (DFID) is that increased income is often spent on shelter, water and power supplies (Department for International Development, 2015). In other words, improvements in shelter, water and power supplies are strong indicators of housing condition. In addition, DFID (2015) opined that better domestic infrastructure is usually a core component of well-being which in the opinions of Sule et al. (2013) and Udoh and Uyanga (2013) is lacking in most rural areas in Nigeria.

Integrated schemes had recorded positive outcome in India, Kenya and Indonesia on livelihood and housing among others according to Majale (2004) and Lall; and Lall (2006). The paper priori expectation is that the experience in Nigeria (though might be different due to differences in political climate, and socio-economic characteristics) could still impact positively on rural housing condition. An integrated scheme was adopted by Rural Development Unit (RUDEP) of Justice Development and Peace Makers' Centre (JDPMC). The JDPMC integrated scheme is chosen for the project because the level of their intervention was more intensive than any other NGOs or educational institution in Osun state. The objective of RUDEP is to improve the livelihood of poorer farmers and they focused on small and medium scale youth farmers and women that engaged in agricultural related activities through enquiries into the socio-economic characteristics of household (HH) heads to obtain their baseline information. In any integrated schemes, there are expected and unexpected outcomes. One of such unexpected outcomes in the scheme being understudied is improvement on rural housing condition. The paper therefore measured the level of contribution of integrated scheme to rural development in Nigeria by establishing the relationship between the integrated rural development scheme, livelihood assets and housing condition in the study area. The remaining part of the paper is structured as follows; following the background is the conceptual framework for the study. Section 3 contains the review of past studies. The research method is discussed in section 4 , while the discussion of research findings and conclusion are in sections 5 and 6 respectively.

\section{Conceptual Framework for the Study}

Integrated approach to housing entails mobilization of community to form self-help group. After obtaining the baseline information from these voluntary group/participants, the scheme is designed to upgrade the participants in terms of skills, credit management, technology, access and linkage to mainstream marketing. The prior expectation is that these social and economic inputs in the livelihood of the participants would generate increase income that would further lead to improvement in housing quality. This scenario is illustrated in Figure 1

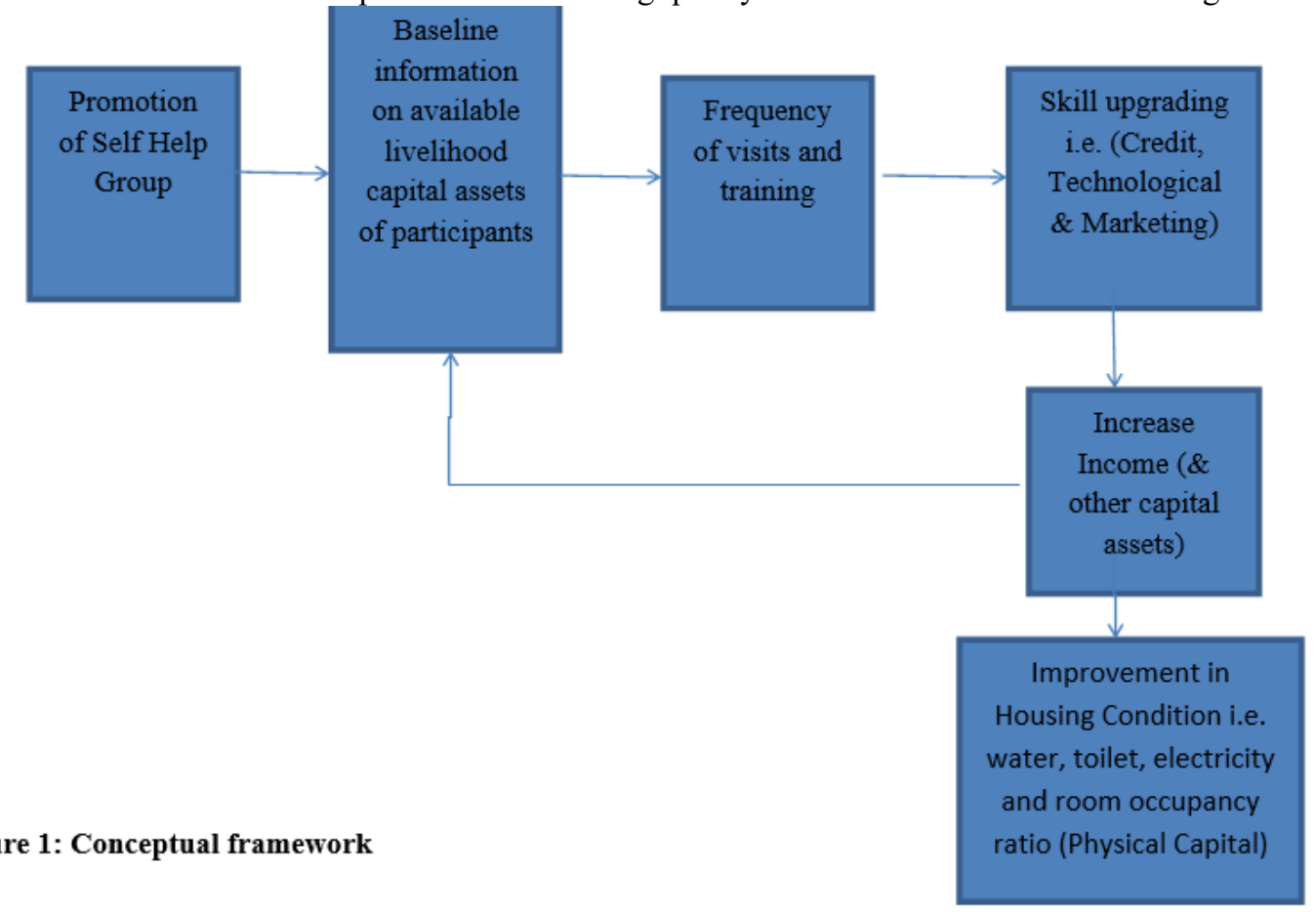




\section{Review of Past Studies}

This section reviews existing works related to the study. There have been various researches on integrated scheme with focus on improvement on farmers' productivity, income, urban slum upgrading among others within and outside Nigeria.

Unwin (1997) provides analysis of rural change in the Baltic state of Estonia. The author uses information obtained from literature reviews. The author opines that an integrated approach to rural development will be a good strategy to boost rural economy in the future. The paper though takes cognizance of the role of integrated approach to boosting rural economy in Estonia is not empirical. Furthermore, the paper only suggests the adoption of integrated approach to enhance rural development in a country that is more advanced than Nigeria.

Shortall and Shucksmith (1998) review literature to enable evaluation of the experienced leader 1 in Scotland and local rural partnerships. To achieve this, the paper focuses on the legitimacy of rural development partnerships and local governance, the goals and process of rural development, the time allocated for pre-development and training of animators. Though the paper is not empirical; it makes suggestion for future European and national rural development policy and practice. But it fails to consider relationship between integrated scheme, livelihood improvement and housing condition in Nigeria which is the focus of the current study.

Mitlin (2000) examines the effectiveness of different strategies used in urban areas by development agencies to reduce poverty. The study used ethnographic approach to improving the future viability of peasant livelihoods in the Andes. The author discovers that there are several factors which suggested that income-generation programmes, when used alone, may not be an effective strategy for reducing poverty. The study also decries the idea of giving too little attention to integrating housing and neighbourhood improvement with income generation. The case studies which the paper used in drawing its conclusion in favour of integrated housing are done outside Nigeria.

Andrew et al. (2001) in their study on the dynamic relationship between assets with different functions and various livelihood activities and processes in pursuit of well-being used preliminary analysis of small livestock keeping by campesinos in south east Mexico. The paper developed a framework that relates the functions and attributes of poor people's assets to their livelihood status and strategies. However, the current study focuses on relationship between integrated scheme, livelihood assets and housing condition using sample of 344 participants on integrated rural development scheme (of rural development programme of Catholic Diocese of Osogbo), in Osun state.

Lall and Lall (2003) decry the non-sustainability of the traditional single component approach in addressing the challenges faced by the poor and the vulnerable in India. These authors used integrated approach to improving housing condition of the urban poor. It was discovered that a key contributory factor to the ineffectiveness of a single component strategy is the thrust on specific components, ignoring the externalities of the impact and target achievement in terms of numerical strength.

The research brought out the inadequacy of providing only secure tenure and access to housing credit to the poor, without being accompanied by income enhancement strategies. While this study achieved similar objective relative to the current paper, the study tested the applicability of integrated strategy in India, which is a different socio-cultural environment when compared to Nigeria. The current paper's objective is to confirm relevance of application of integrated strategy in the Nigeria context.

According to Majale, (2004) in the study to promote a sustainable shelter delivery strategy for the urban poor in Kenya and India used sustainable livelihood approach. The study opines that an integrated approach to urban housing development most certainly has significant potential but it takes time for results to become evident. This study was done in Kenya and India with focus on urban areas while the current paper is examines relationship between income generating activities and housing improvement in rural areas in Nigeria.

Eijsackers et al. (2005) in their study on guide to having effective and efficient process opine that the quality of the process that you set up and follow will make the difference between success and failure. Right at the beginning, it is critical to start building community support by involving people at the start as this will enable them to build a vision, to assume high levels of involvement and to develop ownership.

The study suggests conditions for a good process to include the following: building trust between individuals and the different groups; ensuring that those leading and facilitating the process, and the process itself, are seen as legitimate by key stakeholder groups; inspiring creativity and innovation (new problems will never be solved by thinking and acting in old ways); building robust partnerships and effective teams that can cope with difficult problems among others. The study is a guide to having effective and efficient process and did not implement the process involve in SLA which forms the basis of the current study action plan.

Lall and Lall (2006) test the efficacy of linking shelter provision with income generating activities, for obtaining tangible benefits of improved incomes and an indicator of the process of sustainability being installed at the level of the household. The experiences of the action research in Alwar India established by Lall and Lall (2006) revealed that increase in incomes of the poor generates significant investments in housing and that the process that is initiated tended to become sustainable, based largely on the principles of self-financing. The study 
was based on improving housing condition of the urban poor and was conducted outside Nigeria and not focused on rural housing which is the main thrust of the current study.

Gasu et al. (2010) examine the qualitative housing inadequacy of rural areas in Nigeria and identify escalating cost of building materials, need for a sustained environment, need for provision of affordable building materials, need to provide affordable shelter for all, need to reduce incidence of poverty and need to create employment as factors responsible for current housing needs in the rural areas. The paper however suggests integrated rural development and need to strengthen economic base of the rural areas to improve the revenue generation ability and reduce poverty as part of the recommendation. The current paper focus is in line with implementation of integrated scheme rather than recommendation because the research's major objective is to see whether housing improvement will be the ultimate outcome of increase income.

Yusuf (2010) in his study on gender analysis of livelihood strategies of household heads in rural areas of Osun state, Nigeria, using 252 respondents selected through multi staged sampling opines that there was no difference between male and female heads of household's livelihood strategies but that there are difference in accessibility of each head of household to productive resources among others. The gap is that the study is not focused on the relationship between integrated scheme, livelihood assets and rural housing condition but, concerns with opportunities for different combinations of livelihood strategies opened to the male and female household heads in rural areas of Osun state.

Amao (2014) examines physical and neighbourhood characteristics in housing of Oluyole and Egbeda Local Government Areas in the urban fringes of Ibadan, Nigeria through evaluation of housing quality; identification and examination of influencing factors on housing quality. The study's aim is to informing need for sustainable housing policy in selected urban fringes. The current research work focus is on integrated rural housing development in Nigeria using Sustainable Livelihoods Approach (SLA).

Solomon (2014) embarks on a case study of integrated housing development program in Addis Ababa, Ethiopia with a view to reducing urban poverty and alleviate housing problem in the study area. The finding shows that the program led to the provision of apartments for about one fifth of the residents. It also recorded notable number of apartments that are near completion. The program generated employment opportunities for over 200,000 residents and also led to the upgrading of many slum areas to attractive living and working environment. The current paper defers in that it is focused on relationship between RUDEP's integrated program on livelihood assets and rural housing condition in Nigeria, while Solomon (2014) assessed the impact of integrated scheme in an urban area in Ethiopia.

Ogunkoya, Lasisi, Hassan and Elumah (2015) carry out a time series review on rural development practice in Nigeria. The result reveals that most public efforts on rural development are focused on agricultural development. It also found that the understanding of rural development by policy makers around late 1980s did not led to corresponding improvement in rural development due to factors such as weak institutional arrangements, corruption, and absence of coordinated practice among competing agencies. The paper suggests the adoption of integrated rural development approach to improve the quality of life of the rural people. The paper though based on rural development practice in Nigeria is not empirical and only suggest adoption of integrated rural development approach in rural areas. The current paper's focus is on evaluation of the relationship between an existing integrated rural development scheme, livelihood assets and rural housing condition in Nigeria.

Uddin, Chowdhury and Ahmad (2015) examine challenges and poverty reduction strategies of rural development program (RDP). The study selected 192 poor household randomly from four villages in Bangladesh. The findings show that the RDP, housing and agriculture, health and education have significant impact on poverty alleviation among the poor people. The study defers from the current paper in that it only adopted multisectoral approach to rural development while the current paper is focused on the relationship between RUDEP's integrated program, livelihood assets and rural housing condition in Nigeria using 344 respondents from 28 villages.

Milada, Antonin and Katerina (2015) use analysis of the frequency, travel time, and public transport fare to conduct comparative analysis of demographic development on rural areas in Czech Republic. The result is used to present urbanization processes. The finding is not focus on the influence of integrated scheme on livelihood and housing condition in the rural areas. Moreover, the paper uses facts of Czech Republic which is more advanced economically than Nigeria.

Salemink, Strijker and Bosworth (2015) in the study of rural development in the digital age reviewed 157 papers on digital developments and rural developments in advanced countries. The paper distinguishes research into connectivity research and inclusion research. The finding shows that the hampered diffusion of technologies and the lower average levels of education and skills in rural areas have negative impact on adoption and use. The paper concludes that the rural areas that need digital connectivity most to enable cushioning the effect of their remoteness are poorly connected.

The gap is that the paper is not an empirical study and was based on review of papers on rural development in advanced countries. The paper also fails to adopt integrated approach to rural development which is the focus of the current paper. 
Giri (2017) in his evaluation of various government programmes towards poverty alleviation found that there is still poverty related problems in India despite the implementation of these programmes. He opines that all wage employment programmes implemented by the government lacked focus as regards employment provision. The paper under review was only focused on alleviating poverty via implementation of wage employment programmes to aid development of rural areas in India. However, the current paper studies relationship between RUDEP's integrated program on rural dwellers livelihood assets and their housing condition in Nigeria.

\section{Research Methodology}

The study was carried out in Osun state, Nigeria. A multi stage sampling procedure was used to select 344 respondents. At the first stage, the study area (comprising 36 communities) was divided into four administrative zones covered by Rural Development Programme (RUDEP) a unit of Justice Development and Peace Makers' Centre (JDPMC). These zones comprise of; Ijesa, Ila, Osogbo, and Atakumosa. At the second stage, the pilot survey revealed that only 28 communities out of the whole 36 communities have functioning RUDEP farmers' cooperative group. Consequently, the 28 communities with active groups were purposively selected.

Finally, proportional sampling was used to select 80 percent of the total number of participants who are household $(\mathrm{HH})$ heads from each group in each selected communities in all the four administrative zones as detailed in Table 1, giving a total of 344 respondents. Information such as age, HH size, total revenue, livelihood assets and housing condition was elicited from respondents through structured questionnaire. The data collected was analysed with the use of frequency distribution, correlation, regression and chi-square analysis.

$\mathrm{Y}=\mathrm{a}+\mathrm{bX}_{1}+\mathrm{bX} \mathrm{X}_{2}$

Where

$\mathrm{Y}=$ Housing condition

$\mathrm{a}=$ regression constant

$\mathrm{b}=$ regression coefficient of livelihood asset

$\mathrm{X}_{1}=$ change in household size

$\mathrm{X}_{2}=$ change in livelihood asset

$\mathrm{Y}=2.372+0.240\left(\mathrm{X}_{1}\right)+0.403\left(\mathrm{X}_{2}\right)$

The regression equation shows that changes in independent variables X1 and X2 will lead to change in dependent variable $Y$.

Table 1. Distribution of respondents by location and Local Government Area

\begin{tabular}{|c|c|c|c|c|c|}
\hline S/No & $\begin{array}{l}\text { Administrative } \\
\text { Zone }\end{array}$ & $\begin{array}{l}\text { Farmers Group/ } \\
\text { Communities }\end{array}$ & $\begin{array}{l}\text { Number of } \\
\text { Participants }\end{array}$ & $\begin{array}{l}\text { Number selected } \\
(80 \text { percent })\end{array}$ & $\begin{array}{l}\text { Local } \\
\text { Government Area }\end{array}$ \\
\hline 1 & Atakumosa & $\begin{array}{l}\text { Ifewara } \\
\text { Iganga } \\
\text { Iwara } \\
\text { Iyinta } \\
\text { Olowu } \\
\text { Ajumobi Igangan } \\
\text { Oke-Agbede }\end{array}$ & $\begin{array}{l}26 \\
7 \\
7 \\
12 \\
9 \\
10 \\
18\end{array}$ & $\begin{array}{l}21 \\
6 \\
6 \\
10 \\
7 \\
8 \\
14\end{array}$ & $\begin{array}{l}\text { Atakumosa West } \\
\text { Atakumosa East } \\
\text { Atakumosa East } \\
\text { Atakumosa East } \\
\text { Atakumosa East } \\
\text { Atakumosa East } \\
\text { Atakumosa East }\end{array}$ \\
\hline 2 & Ijesha & $\begin{array}{l}\text { Iwaraja } \\
\text { Asaobi } \\
\text { Ido-Ayegunle } \\
\text { Ila-Ijesha } \\
\text { Epe }\end{array}$ & $\begin{array}{l}11 \\
10 \\
8 \\
16 \\
12\end{array}$ & $\begin{array}{l}9 \\
8 \\
6 \\
13 \\
10\end{array}$ & $\begin{array}{l}\text { Oriade } \\
\text { Atakumosa West } \\
\text { Obokun } \\
\text { Atakumosa West } \\
\text { Atakumosa East }\end{array}$ \\
\hline 3 & Ila & $\begin{array}{l}\text { Idi-Odan } \\
\text { Abalagemo } \\
\text { Oke-Ila } \\
\text { Aiyetoro Ominla } \\
\text { Oyi-Ayegun } \\
\text { Oyi-Araromi }\end{array}$ & $\begin{array}{l}40 \\
10 \\
10 \\
15 \\
36 \\
5\end{array}$ & $\begin{array}{l}32 \\
8 \\
8 \\
12 \\
29 \\
4\end{array}$ & $\begin{array}{l}\text { Ifedayo } \\
\text { Ifedayo } \\
\text { Ifedayo } \\
\text { Ifedayo } \\
\text { Ifedayo } \\
\text { Ifedayo }\end{array}$ \\
\hline
\end{tabular}




\begin{tabular}{llllll}
\hline S/No & $\begin{array}{l}\text { Administrative } \\
\text { Zone }\end{array}$ & $\begin{array}{l}\text { Farmers Group// } \\
\text { Communities }\end{array}$ & $\begin{array}{l}\text { Number } \\
\text { Participants }\end{array}$ & $\begin{array}{l}\text { Number selected } \\
\mathbf{( 8 0} \text { percent) }\end{array}$ & $\begin{array}{l}\text { Local } \\
\text { Government Area }\end{array}$ \\
\hline $\mathbf{4}$ & Osogbo & Ijabe & 11 & 9 & Odo Otin \\
& & Abaolota & 9 & 7 & Boluwaduro \\
& & Abaolode & 20 & 16 & Boluwaduro \\
& Awosun & 27 & 22 & Ife North \\
& Adejuwon & 30 & 24 & Ede North \\
& Elewure & 13 & 10 & Ede South \\
& Owode & 16 & 13 & Ede North \\
& & Oyan & 15 & 12 & Odo Otin \\
& Idominasi & 7 & 6 & Obokun \\
\hline Total & Imesi-Ile & 17 & 14 & Obokun \\
\hline
\end{tabular}

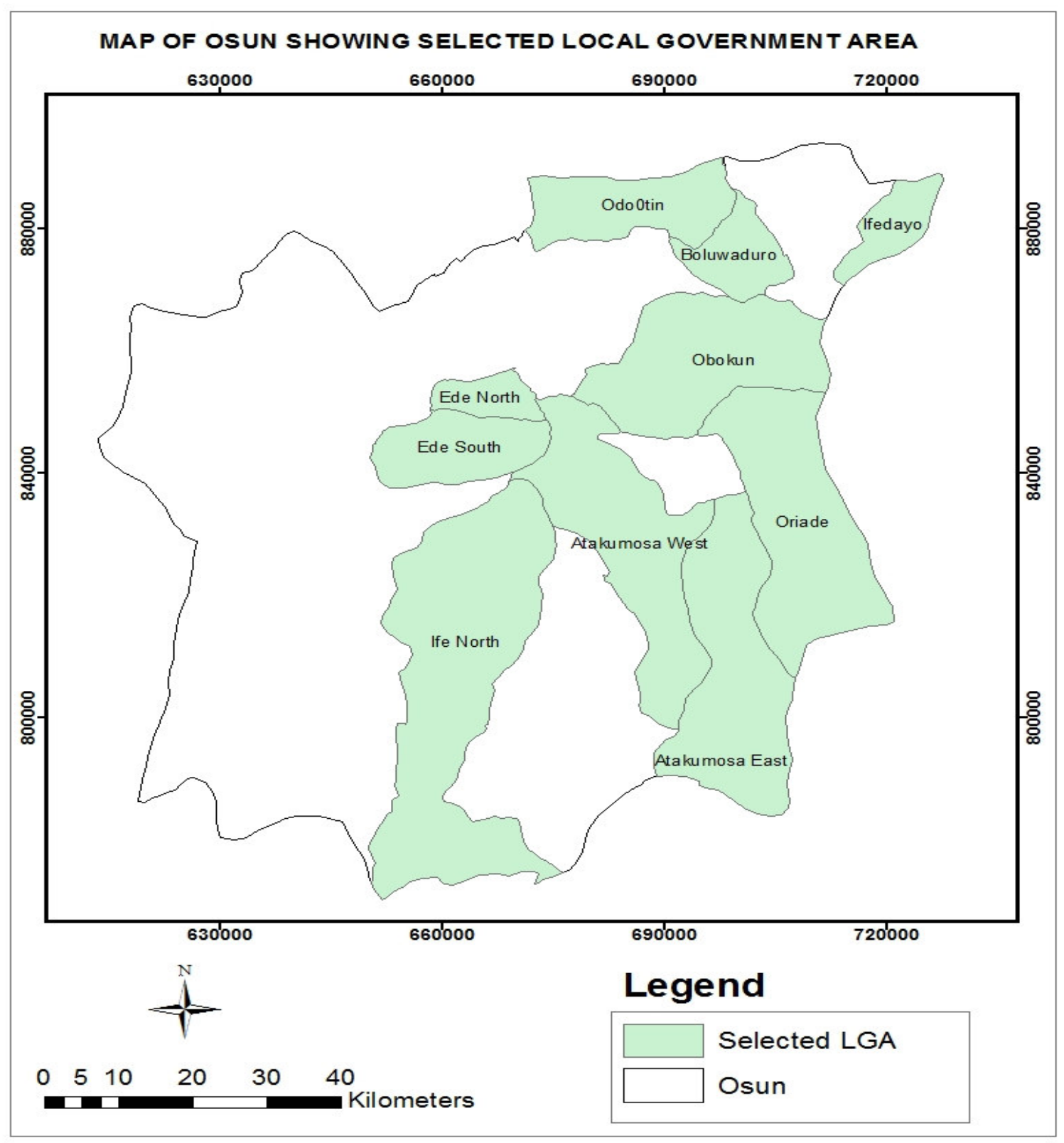

Figure 2: Selected Local Government Area in Osun State 


\section{Discussion of Research Findings}

The result in respect of the relationship between integrated scheme, livelihood assets and housing condition of all the participants was presented in Table $2-4$. The study examined livelihood assets of all the participants' i.e. human, social, financial, physical and natural capital assets. The housing conditions examined in the study were access to water, toilet, electricity and adequacy of accommodation space. These were grouped as livelihood assets and housing conditions for ease of analysis. Table 2 presented the correlation analysis, Table 3 presented the regression analysis and chi-square analysis is in Table 4.

Table 2: Correlation matrix of variables

\begin{tabular}{|c|c|c|c|c|c|}
\hline Variables & 1 & 2 & 3 & 4 & 5 \\
\hline 1. Age & & & & & \\
\hline 2. Household Size & $.259^{* *}$ & & & & \\
\hline 3. Total revenue & -.091 & .042 & & & \\
\hline 4. Livelihood Asset & -.021 & $.217^{* *}$ & $.462^{* *}$ & & \\
\hline 5. Total housing condition & .092 & $.327^{* *}$ & .129 & $.451^{* *}$ & \\
\hline
\end{tabular}

Results in Table 2 shows that household size $(\mathrm{r}=0.327)$ and livelihood assets $(\mathrm{r}=0.451)$ at $\mathrm{P} \leq 0.01$ were found to have positive significant correlation with housing condition. Hence, it seems that the higher the household size and the more the livelihood assets acquired by respondents, the better the housing condition. The variation in housing condition explained by the coefficient of determination $\left(\mathrm{r}^{2}\right)$ shows that household size accounted for 10.7 percent while, livelihood assets accounted for 20.3 percent. This implies that respondents with more livelihood assets and higher household size are most likely seem to have better housing condition and that the housing condition gets better as the livelihood assets and household size increase. This is in consonance with Morse et al. (2009) that large HH size in which most of the members are in working age can lead to increase capacity of the $\mathrm{HH}$ to generate higher income than family with small household $(\mathrm{HH})$ size.

Table 3a: Result of regression analysis

\begin{tabular}{lllllll}
\hline Variable & B & t & R & $\mathbf{R}^{\mathbf{2}}$ & F & P \\
\hline (Constant) & 2.372 & 2.891 & & & & \\
Household Size & 0.165 & 3.737 & 0.512 & 0.254 & 33.374 & $<.01$ \\
Livelihood Asset & 0.155 & 6.283 & & & & \\
\hline
\end{tabular}

Results in Table 3 a shows that both household size and livelihood assets are statistically significant predictors when subjected to regression analysis. The correlation coefficient $0.512(\mathrm{R})$ value for the regression is an indication that there is a moderate association between the household size, livelihood assets and housing condition. The $\mathrm{R}^{2}$ value was 0.262 and adjusted $\mathrm{R}^{2}$ value was 0.254 which means that the regression model accounted for 25.4 percent variation in housing condition. The $\mathrm{F}$-value is 33.374 and is significant at $\mathrm{P} \leq 0.01$ shows that the variable explained by the regression model was not due to probability but as a result of increase in livelihood assets and $\mathrm{HH}$ size. The beta coefficient for the household size is 0.240 at $\mathrm{p} \leq 0.01$ while that of livelihood assets was 0.403 at $\mathrm{p} \leq 0.01$. This indicates that rural dwellers with larger household size and more livelihood assets have better housing condition.

Table 3b: Regression of transformed function of variables

\begin{tabular}{lllllll}
\hline Variable & B & t & $\boldsymbol{R}$ & $\boldsymbol{R}^{2}$ & F & P \\
\hline Constant & -8.579 & -3.698 & & & & \\
Log10_Livelihood Assets & 10.011 & 6.360 & .508 & .258 & 32.628 & $<.01$ \\
Log10_Household Size & 2.757 & .756 & & & & \\
\hline
\end{tabular}

The result in the Table $3 \mathrm{~b}$ above shows that the regression analysis of the transformed function of household size and livelihood assets are statistically significant predictors of housing condition. The correlation coefficient (R) 0.508 reveals that there is a moderate association between the household size, livelihood assets and housing condition. The result is also an indication that both livelihood assets and household size accounted for $25 \%$ of the variance in housing conditions $\left(\mathrm{R}^{2}=.258, \mathrm{~F}(2,188)=32.628, \mathrm{p}<.01\right)$ significantly.

Table 4: Result of chi-square analysis

\begin{tabular}{lccc}
\hline & $\mathbf{x}^{\mathbf{2}}$ value & Degree of freedom & Contingency coefficient (C) \\
\hline Nature of intervention & 5.921 & 9 & 0.748 \\
Frequency of RUDEP visit & 6.507 & 8 & 0.243 \\
\hline
\end{tabular}

Chi-square analysis result in Table 4 shows the association between mode of RUDEP (a department of JDPMC) scheme and housing condition. The modes of RUDEP scheme operation are the mode of operation adopted for intervention by RUDEP to reduce the negative impact of the hazards experienced by farmers and frequency of RUDEP visit. Chi-square result $\left(\chi^{2}=5.921, p \leq 0.01\right)$ reveals that JDPMC rural integrated scheme have significantly improved the households' housing condition in the study area. It implies that the mode of operation and housing condition are not independent of each other, and that their relationship is positive. 


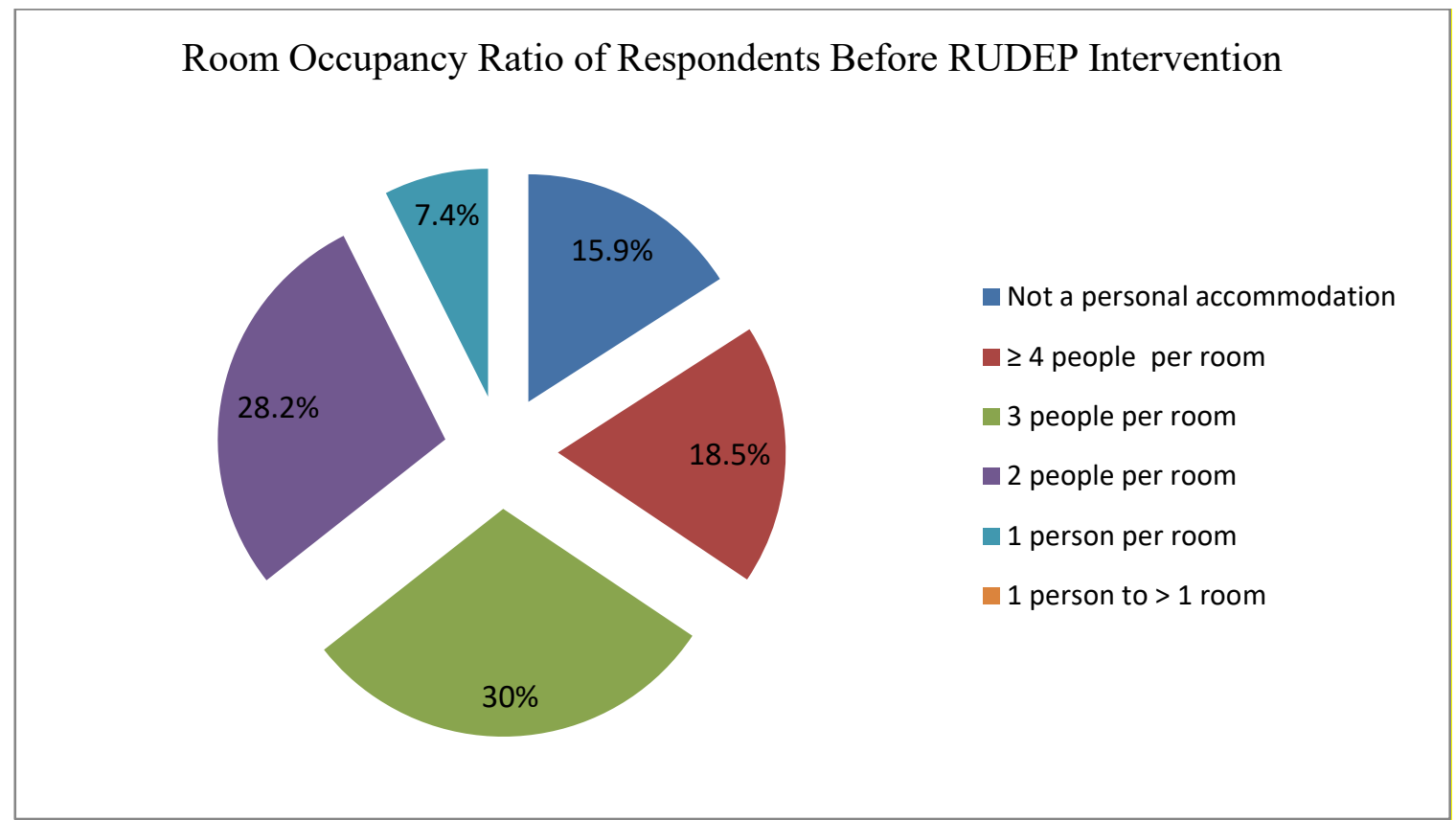

Figure 3: Room occupancy ratio of respondents living in personal accommodation

Figure 3 and 4 reveal the room occupancy ratio before and after the RUDEP intervention to further buttress the housing condition of respondents in the study area. Before the intervention, information obtained from Figure 3 reveals that few respondents 7.4 percent have a room to themselves, and none of the respondents have occupancy ratio of more than a room per person. Moreover, 28.2 percent respondents shared a room with a person, and 30 percent have occupancy ratio of 3 persons per room and 18.5 percent have greater than or equal to four persons per room. This implies that 76.7 percent of the respondents share a room with others. However, 48.5 percent of respondents that shared a room with others are experiencing overcrowding. This could be because most farmers have young families then in which most of the children were still within secondary school age. It could also be due to some of the 15.9 percent farmers that do not have personal accommodation that are staying with those that have personal accommodation.

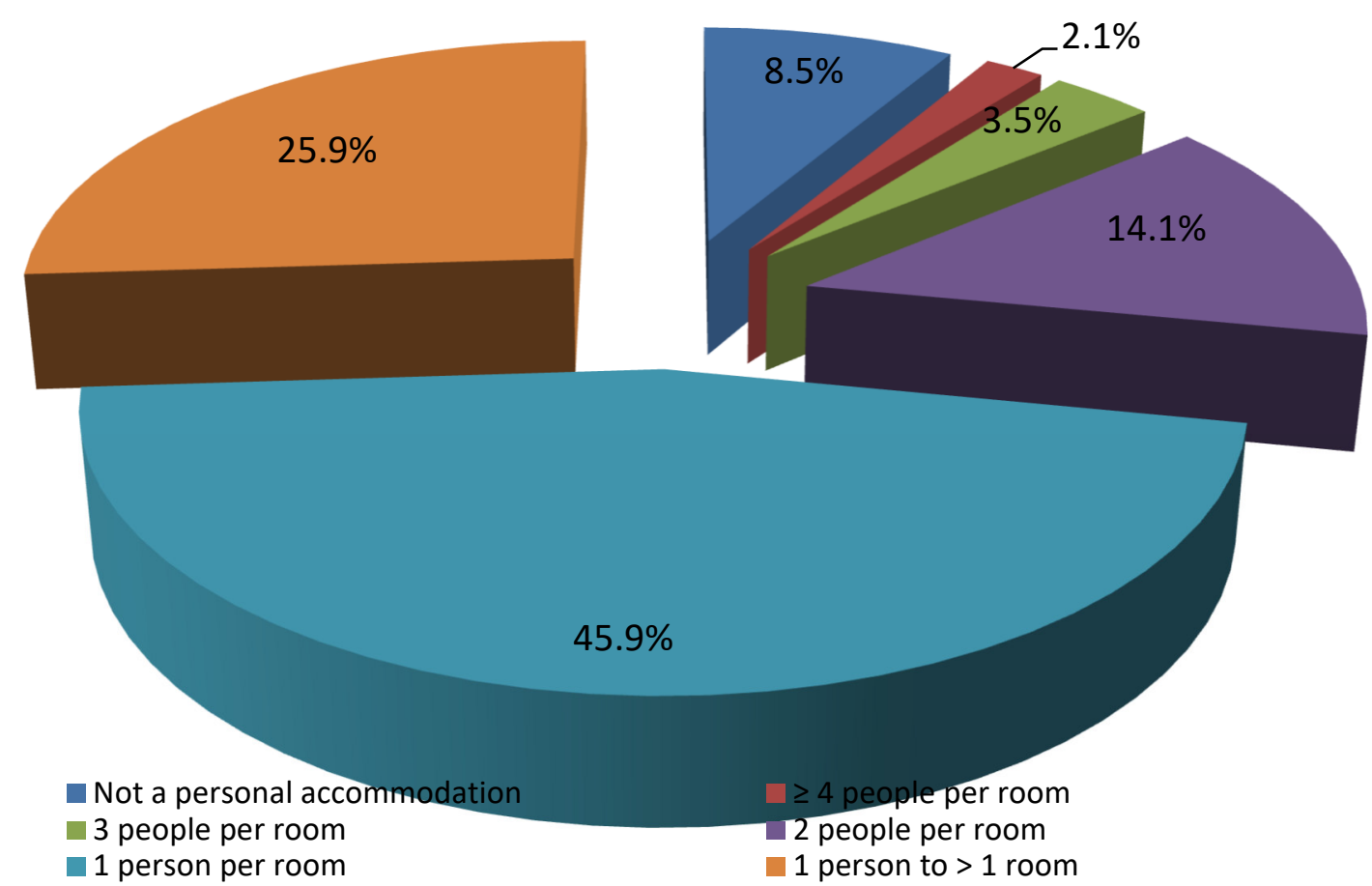

Figure 4: Room occupancy ratio of respondents living in personal accommodation after the intervention

Furthermore, information from Figure 4 reveals that more of the respondents 45.9 percent have a room to themselves, 25.9 percent of respondents have occupancy ratio of more than a room per person. It implies $71.8 \%$ 
respondents has minimum of a room to themselves, while 14.1 percent respondents shared a room with a person, and 3.5 percent have occupancy ratio of 3 persons per room and only 2.1 percent have greater than or equal to four persons per room. The implication is that about 20 percent of the respondents share a room with others, and only 5.6 percent respondents that shared a room with others are experiencing overcrowding. This is a notable drift from initial 76.7 percent of the respondents that shared a room with others and 48.5 percent of respondents among those that shared a room with others who are experiencing overcrowding before the RUDEP intervention. However, those with room occupancy ratio of a person per room and more than a room to a person fall among the old farmers with no dependant or children staying with them as observed during the field work. This could be an indicator of lack of many youth farmers in the study area.

\section{Conclusion}

The paper evaluated the relationship between integrated rural development scheme, livelihood assets and housing condition in rural areas in Nigeria. The chi-square shows that the mode of operation and housing condition are not independent of each other, and that their relationship is positive. The study revealed that there is significant correlation between livelihood assets, household size and housing condition, and that the housing condition gets better as the livelihood assets and household size increases. The room occupancy ratio also shows decrease in the number of respondents that are crowded in a room. The results in correlation and regression analysis tallies with findings of Majale, (2004) and Lall and Lall (2006) that an integrated approach to urban housing development most certainly has significant potential on improving housing condition in Kenya. It is also similar to the experience of the action research in Alwar India which established that increase in incomes of the poor generates significant investments in housing. The paper is also an addition to empirical studies and theories in the field of integrated schemes. Based on these findings, it implies that integrated housing has the potential to improve rural housing condition in Nigeria. The study therefore suggests that integrated scheme should be considered as an effective self-financing rural housing improvement strategy in Nigeria.

\section{References}

Amao F.L. (2014). Housing Quality in Selected Urban Fringes of Ibadan, Nigeria. (Unpublished MPhil thesis). Obafemi Awolowo University.

Andrew D., Simon A., Susanne C., Bernadette K., Julieta M. (2001). Asset Functions and Livelihood Strategies: A Framework for Pro Poor Analysis, Policy and Practice. Paper presented at the EAAE Seminar 2001 on Livelihoods and Rural Poverty. Retrieved from https://ideas.repec.org/p/ags/icwywp/10918.htm on December 6, 2016.

Department for International Development (DFID) (2015). Sustainable Livelihood Guidance Sheets: DFID.

Eijsackers D., Holst F., Jávor K., Kovács K., Magócs K., Sain M., Vugt S., \& Woodhill J., (2005). Practice of Integrated Rural Development (PRIDE). A guide for participatory planning in Hungary. Presented at the Institute for Regional Planning and Urbanism (VÁTI), Central and Northern Hungarian Research Institute. Retrieved from http://citeseerx.ist.psu.edu/viewdoc/download?doi=10.1.1.198.8051\&rep=rep1\&type=pdf on December 6, 2016

Gasu M.B., Fadare S.O. and Olayiwola K.O. (2010). Rural Housing Needs and Responses: Challeges and Prospects in Nigeria. An International Journal of Comtemporary Urban and Regional Development from Multidisciplinary Perspectives. 2 (1\&2), 41-50.

Giri A.K., (2017). Rural Development in India: Through Employment Programmes. International Journal of Scientific Research and Management. 5(7), 6150-6154.

IFAD. (2011). Rural Poverty in Nigeria. International Fund for Agricultural Development. http://www.ruralpovertyportal.org/web/guest/country/home/tags/nigeria. Accessed on April 27, 2018.

India (2015). Rural Housing Schemes in India. - A Resume'. Retrieved from http://shodhganga.inflibnet.ac.in:8080/jspui/bitstream/10603/159/3/12_chapter3.pdf, October 2, 2015.

Kenya (2004). National Housing Policy for Kenya. Presented as Sessional Paper No.3 2004, Ministry of Housing,

Kenya. Retrieved from http://www.mintoreal.com/policy-documents/kenya-national-housing-policy on December $5,2016$.

Lall, S (2002a). Housing for the Poor and Urban Development - The Indian Dynamics. Retrieved from http:// www.itdg.org/docs/shelter/iuhd_wp5_housing_for_the_poor.pdf on February 10, 2016.

Lall, S (2002b). An Evaluation of a Public Sector Low Income Project in Alwar: India, Presented at Society for Development $\quad$ Studies $2002 . \quad$ Retrieved from http://itdg.org/docs/32shelter/iuhd_wp6_evaluation_of_public_sector_low_income.pdf

Lall, S., and Lall, V.D., (2006). Society for Development Studies New Delhi, India. January 2006 Retrieved from www.sdindia.org on Decenver 5, 2016.

Majale M (2004). An Integrated Approach to Urban Housing Development: Has a Case Been Made? Global Urban Research Unit School of Architecture, Planning and Landscape, University of Newcastle, E- mail: 
m.m.majale@ncl.ac.uk.

Milada S, Antonin V, and Katerina S. (2015). Integrated Transport System of the South-Morovian Region and its Impact on Rural Development. Transportation Research Part D 36, 53-64.

Mitlin D., (2000). Addressing urban poverty: increasing incomes, reducing costs, and securing representation. Development in Practice, 10 (2), 204-215

Morse S., McNamara N. and Acholo M. (2009). Sustainable Livelihood Approach: A Critical Analysis of Theory and Practice. Geographical Paper No. 189, University of Reading.

Retrieved from http://www.reading.ac.uk/nmsruntime/saveasdialog.aspx?IID=48667 on May, 24, 2014.

Nahiduzzaman, K.M., (2012). Housing the Urban Poor: an Integrated Governance Perspective. The Case of Dhaka, Bangladesh. (Unpublished Ph.D Thesis). Royal Institute of Technology (KTH), Stockholm.

Odebode A.A. and Oladokun T.T. (2010). Public Private Partnership in Housing Delivery in Nigeria. In Fadare, S.O. and D.A. Adesanya (Eds). Sustainable Environment. 132-142 Ile-Ife: Obafemi Awolowo University Press.

Ogunkoya O.A., Lasisi J.O., Hassan B., and Elumah L.O. (2015). International Journal of African and Asian Studies. www.iiste.org. 11, 78-83. Accessed on April 27, 2018.

Olayiwola L.M., and Adeleye O.A. (2005). Rural Infrastructural Development in Nigeria: Between 1960 and 1990Problems and Challenges. Journal of Social Science. 11(2), 91-96.

Salemink K., Strijker D., and Bosworth G. (2015). Rural Development in the Digital Age: A Systematic Literature Review on Unequal ICT Availability, Adoption, and Use in Rural Areas. Journal of Rural Studies. 1-12. www.elsevier.com/locate/jrurstud.

Shortall S., and Shucksmith M. (1998). Integrated Rural Development: Issues Arising from The Scottish Experience. European Planning Studies. 6(1), 73-88.

Solomon K., (2014). Integrated Housing Development Program (IHDP) As Instrument to Alleviate Urban Poverty. The Case of Addis Ababa. Emerging Challenges - Enhancing the Relevance. FIG Congress, 16-21 June, 2014, Kuala Lumpur, Malasia.

Sule, I.G., Alinno, F.C., and Ikwegbe, D., (2013). Rural Economic Developement: Policy Implementation in Nigeria. International Journal of Academic Research in Business and Social Sciences. 3(2), 24-36.

Uddin M.M., Chowdhury M.M., and Ahmad A., (2015). The Impact of Rural Development Program on Poverty Alleviation: A Case of Bangladesh. Global Journal of Management and Business Research: A Administration and Management. 15(4), 17-24.

Udoh U., and Uyanga J. (2013). Housing Conditions and Health in Rural Nigeria: A Study of Akwa Ibom State. Research on Humanities and Social Sciences www.iiste.org. 3 (18). 34-41.

Unwin T (1997). Agricultural Restructuring and Integrated Rural Development in Estonia. Journal of Rural Studies. 13(1). 93-112.

Yusuf O.J., (2010). Gender Analysis of Livelihood Strategies of Household Heads in Rural Areas of Osun State, Nigeria. (Unpublished M.Phil Thesis) Obafemi Awolowo University. 